\title{
Optimalisasi Penggunaan Model Pembelajaran Word Square untuk Meningkatkan Hasil Belajar Siswa pada Tema Makanan Sehat di Kelas V SD Negeri 168/X Pandan Sejahtera
}

\author{
Nopri Samdi \\ SD Negeri 168/X Pandan Sejahtera \\ Jl. Singosari, Pandan Sejahtera, Kec. Geragai, Kab. Tanjung Jabung Timur Prov. Jambi \\ noprisamdi2021@gmail.com
}

\begin{abstract}
This study aims to disclose information and discuss the Optimization of the use of the Word Square Learning Model to Improve Student Learning Outcomes on the Theme of Healthy Food In Class V SD Negeri 168/X Pandan Sejahtera.This research is included in the type of classroom action research (CAR). This research was carried out in this research was carried out at SD Negeri 168/X Pandan Sejahtera. The time of this research was carried out in the odd semester of the academic year 2021 - 2022, which began in September 2021. The subjects in this study were class $\mathrm{V}$ students, totaling 21 people. The research procedure consisted of two cycles with four stages of research starting from planning, implementing, observing and reflecting. Data collection in this study was carried out using field notes, student worksheets, written tests, and documents. The data were analyzed using the percentage formula. The results of this study indicate that the Word Square Learning Model on the Healthy Food Theme can improve student learning outcomes in class V SD Negeri 168/X Pandan Sejahtera which is marked by an increase from pre-cycle (14\%), cycle I (57\%), cycle II (91\%).
\end{abstract}

Keywords: Learning Outcomes, Word Square Learning Model.

\begin{abstract}
Abstrak
Penelitian ini bertujuan untuk mengungkapkan informasi dan membahas tentang Optimalisasi Penggunaan Model Pembelajaran Word Square untuk Meningkatkan Hasil Belajar Siswa pada Tema Makanan Sehat di Kelas V SD Negeri 168/X Pandan Sejahtera. Penelitian ini termasuk dalam jenis penelitian tindakan kelas (PTK). Penelitian ini dilaksanakan di Penelitian ini dilaksanakan di SD Negeri 168/X Pandan Sejahtera. Waktu penelitian ini dilaksanakan pada semester ganjil tahun pelajaran 2021 - 2022, yang dimulai pada bulan September 2021. Subjek dalam penelitian ini adalah siswa kelas V yang berjumlah 21 orang. Prosedur penelitian terdiri dari dua siklus dengan empat tahap peneletian mulai dari perencanaan, pelaksanaan, observasi dan refleksi. Pengumpulan data dalam penelitian ini dilakukan dengan menggunakan teknik catatan lapangan, lembar kerja siswa, tes tertulis, dan dokumen. Data dianalisis dengan menggunakan rumus persentase. Hasil penelitian ini menunjukkan bahwa Melalui Model Pembelajaran Word Square Pada Tema Makanan Sehat dapat meningkatkan hasil belajar siswa di kelas V SD Negeri 168/X Pandan Sejahtera yang ditandai oleh meningkatnya dari pra siklus (14\%), siklus I (57\%), siklus II (91\%).
\end{abstract}

Kata Kunci : Hasil Belajar, Model Pembelajaran Word Square.

Copyright (c) 2021 Nopri Samdi

Corresponding author: Nopri Samdi

Email Address: noprisamdui2021@gmail.com (Jl. Singosari, Pandan Sejahtera, Kec. Geragai, Jambi)

Received 01 December, Accepted 13 December 2021, Published 28 December 2021

\section{PENDAHULUAN}

Tujuan umum pendidikan untuk membentuk peserta didik yang mandiri dalam konteks kehidupan pribadinya, bermasyarakat, berbangsa dan bernegara, serta sebagai makhluk Tuhan beragama. Selain itu, memberikan bekal kepada peserta didik supaya mampu hidup layak dan dapat hidup bermasyarakat dengan baik. Melalui pengetahuan, keterampilan, dan kreativitas yang dimiliki, 
mereka mampu mencari nafkah dengan baik sesuai dengan tingkatannya dan dapat melanjutkan studi ke jenjang yang lebih tinggi. Pemerintah dalam hal ini adalah sekolah merupakan ujung tombak pencapaian tujuan pendidikan. Guru sebagai tenaga pendidik mempunyai peran penting dalam pelaksanaan pendidikan di sekolah.

Di Negara Republik Indonesia sudah dijelaskan dalam Undang-Undang Dasar 1945 pasal 31 ayat 1 yang berbunyi "Setiap warga negara berhak mendapatkan pendidikan". Secara spesifik pada Undang-Undang nomor 20 tahun 2003 tentang Sistem Pendidikan Nasional dijelaskan tujuan pendidikan nasional adalah : "Pendidikan nasional berfungsi mengembangkan kemampuan dan membentuk watak serta peradaban bangsa yang bermartabat dalam rangka mencerdaskan kehidupan bangsa, bertujuan untuk berkembangnya potensi siswa agar menjadi manusia yang beriman dan bertaqwa kepada Tuhan Yang Maha Esa, berakhlak mulia sehat, berilmu, cakap, kreatif.

Berdasarkan Undang-Undang Guru dan Dosen pasal 1 ayat (1) (dalam Iskandar, 2009: 1) menyebutkan guru adalah pendidik profesional dengan tugas utama mendidik, mengajar, membimbing, mengarahkan, melatih, menilai dan mengevaluasi peserta didik pada pendidikan anak usia dini jalur pendidikan formal, pendidikan dasar dan pendidikan menengah. Pelaksanaan peran tersebut menjadikan tugas dan tanggung jawab guru menjadi berat. Ini mengakibatkan guru mempunyai peran ganda di sekolah. Selain mengajar, guru harus memberikan tuntunan, bimbingan, asuhan, latihan dan teladan kepada siswa serta melaksanakan menilai dan mengevaluasi siswa dalam kelas.

Dalam rangka pencapaian pembelajaran secara optimal pada waktu proses belajar mengajar di dalam kelas serta untuk pencapaian tujuan pendidikan, guru dituntut harus memiliki kemampuan dan keterampilan dalam rangka mengelola kemampuan pengajaran. Proses belajar mengajar tidak hanya ditandai oleh keaktifan guru saja, namun disini dituntut juga siswa harus mampu aktif dan berhasil dalam pembelajaran yang ditandai dengan ketuntasan hasil belajar siswa.

Namun berdasarkan kenyataan yang ditemukan dalam proses pembelajaran di SD Negeri 168 / X Pandan Sejahtera diperoleh data sebagian siswa banyak hasil belajarnya dibawah KKM (60), khususnya di kelas V. Dari 21 jumlah siswa kelas V hanya 3 (14\%) orang yang hasil belajarnya melewati KKM (70). Rendahnya hasil belajar siswa menggambarkan rendahnya tingkat kemampuan siswa.

Berdasarkan hasil observasi awal pada kelas V SD Negeri 168 / X Pandan Sejahtera ditemukan bahwa rendahnya hasil belajar siswa juga dipengaruhi oleh model pembelajaran yang digunakan selama proses pembelajaran kurang tepat terhadap materi yang dipakai. Maka peneliti mencoba untuk melakukan perubahan dengan menggunakan model pembelajaran Word Square. Menurut Istarani (2012: 180) model pembelajaran Word Square merupakan 13 model pembelajaran yang memadukan kemampuan menjawab pertanyaan dengan kejelian dalam mencocokkan jawaban pada kotak-kotak jawaban. 
Optimalisasi Penggunaan Model Pembelajaran Word Square untuk Meningkatkan Hasil Belajar Siswa pada Tema Makanan Sehat di Kelas V SD Negeri 168/X Pandan Sejahtera, Nopri Samdi

Penelitian ini bertujuan untuk mendapatkan informasi dan membahas tentang Optimalisasi Penggunaan Model Pembelajaran Word Square Untuk Meningkatkan Hasil Belajar Siswa Pada Tema Makanan Sehat Di Kelas V SD Negeri 168/X Pandan Sejahtera.

Proses belajar merupakan bentuk prilaku manusia yang sangat penting dan utama bagi kelangsungan hidup manusia. Proses belajar membantu manusia menyesuaikan diri dengan lingkungan di sekitarnya agar ia dapat mempertahankan kelangsungan hidupnya. Banyak pengertian belajar yang dikemukakan oleh para ahli, salah satunya menurut Gagne (1984), bahwa belajar adalah suatu proses di mana suatu organisme berubah prilakunya sebagai akibat pengalaman (Strategi Belajar Mengajar, 2004:2.3), Juga menurut Gagne (1984) belajar dapat didefinisikan sebagai suatu proses di mana suatu organisme berubah akibat pengalaman.

Menurut Trianto (2012:17) Belajar adalah sebagai proses perubahan perilaku tetap dari belum tahu menjadi tahu, dari tidak paham menjadi paham, dari kurang terampil menjadi terampil, dan dari kebiasaan lama menjadi kebiasaan baru, serta bermanfaat bagi lingkungan maupun individu itu sendiri. Menurut Slameto (2010:2) Belajar ialah suatu proses usaha yang dilakukan seseorang untuk memperoleh suatu perubahan tingkah laku yang baru secara keseluruhan, sebagai hasil pengalamannya sendiri dalam interaksi dengan lingkunganya.

Dengan demikian dapat di simpulkan belajar adalah sebagai proses atau kegiatan untuk mendapatkan pengetahuan dan pemahaman, meningkatkan keterampilan, memperbaiki sikap dan perilaku sebagai hasil dari pengalaman sendiri dalam interaksi dengan lingkungan.

Menurut Uno (2011:21) Hasil belajar adalah variable metode dan kondisi pembelajaran, variable hasil pembelajaran juga dapat diklasifikasikan dengan cara yang sama, pada tingkat yang amat umum sekali hasil pembelajaran dapat diklasifikasikan menjadi 3 (tiga) yaitu keefektifan, efesisensi, daya tarik.

Hasil belajar adalah kemampuan yang dimiliki peserta didik setelah ia menerima pengalaman belajarnya (Sudjana, 2002 : 22). Hasil belajar terwujud dalam perubahan tingkah laku dari tidak tahu menjadi tahu dan dari tidak mengerti menjadi mengerti. Hal ini sejalan dengan yang diungkapkan Arikunto (1992 : 7) yang menyatakan bahwa "Tujuan penilaian hasil belajar adalah untuk mengetahui apakah materi yang sudah dipahami oleh peserta didik dan apakah metode yang digunakan sudah tepat atau belum".

Dengan demikian hasil belajar adalah perubahan perilaku secara keseluruhan berupa kemampuan kognitif, afektif, keterampilan, daya tarik, apresiasi dan informasi-informasi verbal.

Menurut Hanafiah (2009:41) menyatakan bahwa model pembelajaran merupakan salah satu pendekatan dalam rangka mensiasati perubahan perilaku peserta didik secara adaptif maupun generatif. Model pembelajaran sangat erat kaitannya dengan gaya belajar peserta didik dan gaya belajar guru.

Menurut Joyce dalam Trianto (2011:142) menyatakan bahwa model pembelajaran adalah suatu perencanaan yang digunakan sebagai pedoman dalam merencanakan pembelajaran di kelas atau 
pembelajaran dalam tutorial dan untuk menentukan perangkat-perangkat pembelajaran termasuk di dalamnya buku-buku, film, komputer, kurikulum, dan lain-lain.

Menurut Suprijono (2009:46) menyatakan bahwa Model Pembajaran adalah pola yang digunakan sebagai pedoman dan merencanakan pembelajaran dikelas maupun tutorial. Menurut Arend model pembelajaran mengacu pada pendekatan yang digunakan, termasuk didalamnya tujuan pembelajaran, tahap tahap dalam kegiatan pembelajaran. Model pembelajaran dapat didefenisikan sebagai kerangka konseptual yang melukiskan prosedur sistematis dalam mengorganisasikan pengalaman belajar untuk mencapai tujuan belajar.

Berdasarkan uraian di atas, maka dapat disimpulkan bahwa model pembelajaran adalah suatu rencana atau pola yang digunakan dalam mengorganisasikan pengalaman belajar, perangkat pembelajaran untuk mencapai tujuan pembelajaran tertentu dan berfungsi sebagai pedoman bagi perancang pembelajaran dan para guru dalam merancang dan melaksanakan proses belajar mengajar.

Model pembelajaran Word Square merupakan pengembangan dari metode ceramah yang diperkaya. Hal ini dapat didefinisikan melalui pengelompokkan metode ceramah yang diperkaya dan berorientasi kepada keaktifan siswa. Menurut Istarani (2012: 180) model pembelajaran Word Square merupakan 13 model pembelajaran yang memadukan kemampuan menjawab pertanyaan dengan kejelian dalam mencocokkan jawaban pada kotak-kotak jawaban.

Word Square menurut Hornby (1994) adalah sejumlah kata yang disusun sehingga katakata tersebut dapat dibaca ke depan dan ke belakang. LKS Word square adalah salah satu alat bantu/media pembelajaran berupa kotak-kotak kata yang berisi kumpulan huruf.

Belajar dan bermain memiliki persamaan yang sama yaitu terjadi perubahan yang dapat mengubah tingkah laku, sikap dan pengalaman, sebaliknya keduanya terdapat perbedaan pada tujuannya, kegiatan belajar mempunyai tujuan yang terletak pada masa depan. Sedangkan kegiatan bermain tujuan kesenangan dan kepuasannya diwaktu kegiatan permainan itu berlangsung. Kemudian, menurut Mujiman (2007: 92), mengemukakan bahwa model pembelajaran Word Square merupakan pengembangan model ceramah yang diperkaya. Hal ini dapat diidentifikasikan dengan pengelompokan metode ceramah yang berorientasi kepada keaktifan siswa dalam pembelajaran. Lebih lanjut, menurut Trianto (2011: 23) Word Square berasal dari Word yang artinya kata dan Square yang artinya persegi, Word Square merupakan model yang menggabungkan kemampuan menjawab pertanyaan dengan kejelian dalam mencocokkan jawaban pada kotak-kotak jawaban.

\section{METODE}

Penelitian ini termasuk dalam jenis penelitian tindakan kelas (PTK). Penelitian ini dilaksanakan di Penelitian ini dilaksanakan di SD Negeri 168/X Pandan Sejahtera. Waktu penelitian ini dilaksanakan pada semester ganjil tahun pelajaran 2021 - 2022, yang dimulai pada bulan September 2021. Subjek dalam penelitian ini adalah siswa kelas V yang berjumlah 21 orang. Prosedur penelitian terdiri dari dua siklus dengan empat tahap peneletian mulai dari perencanaan, pelaksanaan, 
Optimalisasi Penggunaan Model Pembelajaran Word Square untuk Meningkatkan Hasil Belajar Siswa pada Tema Makanan Sehat di Kelas V SD Negeri 168/X Pandan Sejahtera, Nopri Samdi

observasi dan refleksi. Pengumpulan data dalam penelitian ini dilakukan dengan menggunakan teknik catatan lapangan, lembar kerja siswa, tes tertulis, dan dokumen. Data dianalisis dengan menggunakan rumus persentase.

\section{HASIL DAN DISKUSI}

\section{Paparan Data Pra Siklus}

Pra siklus merupakan kondisi awal Model Pembelajaran Word Square sebelum peneliti melakukan kegiatan penelitian di dalam kelas, dengan menggunakan pola pembelajaran konvensional/ceramah. Selanjutnya, berdasarkan hasil data pra siklus yang diperoleh, peneliti bersama guru lain melakukan evaluasi mengenai metode/model pembelajaran yang dianggap tepat, sebagai bentuk tindakan perbaikan dari proses pembelajaran.

Kegiatan pengambilan data pra siklus dilakukan di kelas V dengan jumlah siswa 21 orang. Hasil proses pembelajaran terlihat monoton dan berpusat pada guru, tingkat partisipasi siswa dalam belajar rendah, kurang termotivasi dalam belajar, banyak siswa yang tidak memperhatikan ketika guru menerangkan pelajaran di depan kelas, dan mengobrol bersama temannya, mengantung dan ada juga yang mengganggu temannya yang lain saat pembelajaran berlangsung serta kurang pahamnya siswa saat melakukan tugas yang diberikan oleh guru, sehingga saat mempresentasikan tugas siswa banyak yang tidak siap atau belum tuntas.

Dampaknya hasil belajar siswa juga rendah, ini dibuktikan dari lembar kerja siswa saat belajar, banyak diantara mereka yang tidak tuntas saat mengikuti ulangan harian. Untuk lebih jelasnya dapat dilihat pada tabel dibawah ini:

Tabel 1. Rekapitulasi Hasil Belajar Siswa Pra Siklus

\begin{tabular}{|l|c|}
\hline Jumlah & 1.130 \\
\hline Rata-rata & 53,80 \\
\hline KKM & 60 \\
\hline Siswa yang Tuntas & 3 Orang (14\%) \\
\hline Siswa yang Belum Tuntas & 18 Orang $(86 \%)$ \\
\hline
\end{tabular}

Dari tabel di atas dapat dijelaskan bahwa sebelum menerapkan Model Pembelajaran Word Square di peroleh rata - rata hasil belajar siswa yaitu 53,80 dengan jumlah siswa yang tuntas sebesar $14 \%$ (3 orang siswa) dan selebihnya $86 \%$ belum tuntas (18 orang siswa). Dengan demikian, berdasarkan tabel hasil belajar siswa diatas serta penjelasannya dapat disimpulkan bahwa masih banyak siswa yang belum tuntas dalam belajar.

Sehingga, masih terdapat 18 dari 21 siswa yang belum tuntas belajar atau sebesar $86 \%$. Hasil tersebut lebih kecil dari persentase ketuntasan klasikal dalam proses pembelajaran yang dikehendaki sebesar $80 \%$ siswa yang tuntas dalam belajar dengan KKM sebesar 60. Berdasarkan tabel lembar hasil belajar siswa dan penjelasan pra siklus diatas dapat dilihat lebih jelas pada diagram dibawah ini: 


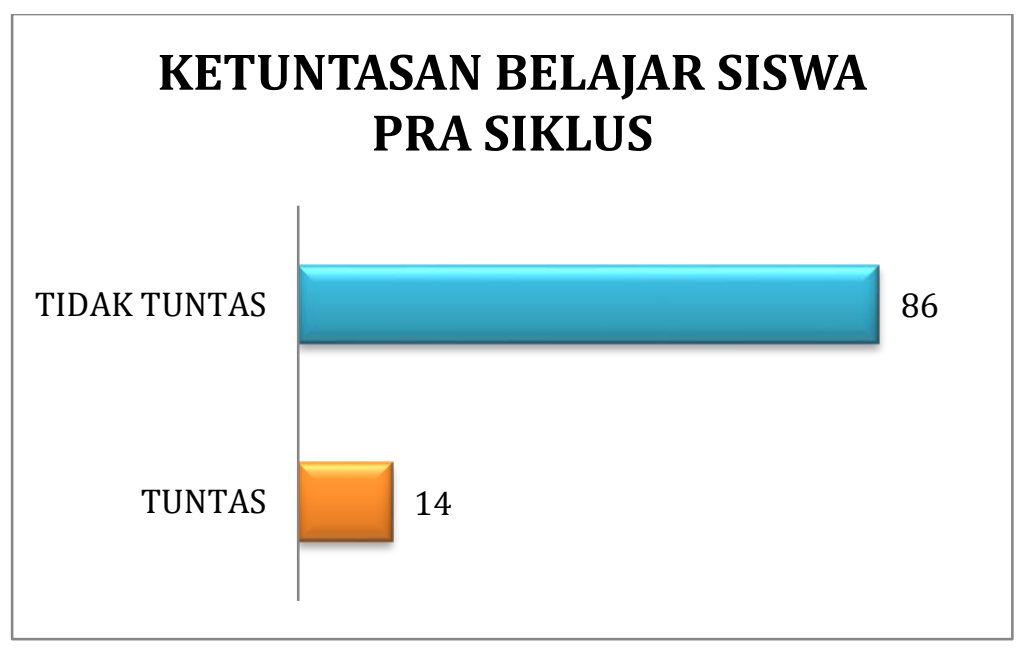

Gambar 1. Ketuntasan Hasil Belajar Siswa Pra Siklus

\section{Hasil Penelitian}

\section{Siklus I}

\section{Tahap Perencanaan}

Berdasarkan hasil pengalaman dan proses pengamatan sehari-hari dan refleksi dari proses belajar mengajar, maka dapat diidentifikasi permasalahan-permasalahan yang terjadi pada peserta didik. Berdasarkan permasalahan yang ditemukan kemudian direncanakan apa yang harus dilakukan untuk memperbaiki proses pembelajaran. Berdasarkan permasalahan yang diperoleh, ditetapkan langkah-langkah perencanaan tindakan sebagai berikut: Peneliti dengan observer mengadakan pertemuan untuk menentukan langkah- langkah yang harus dilaksanakan dalam penelitian ini. Peneliti merencanakan sekenario pembelajaran yang sesuai dengan kurikulum dan tingkat kemampuan awal siswa berdasarkan hasil kesepakatan bersama dengan observer untuk menyusun sekenario pembelajaran. Adapun sekenario pembelajaran sebagai berikut: Menyiapkan rencana pembelajaran sesuai dengan tujuan yang akan dicapai dalam mata pelajaran. Menyampaikan tujuan pembelajaran yang ingin dicapai. Perencanaan kegiatan inti pembelajaran dengan meggguanakan format penilaian yang sudah ditentukan. Merancang LKS yang akan digunakansaat siswa mengikuti kegiatan pembelajaran. Menyiapkan materi pembelajaran yang diperlukan saat berlangsungnya pembelajaran. Merencanakan model pembelajaran yang akan digunakan saat berlangsungnya penelitian. Menyiapkan format pengamatan proses pembelajaran saat berlangsungnya penelitian. Menyiapkan format penilaian hasil belajar.

\section{Tahap Pelaksanaan}

Pelaksanaan kegiatan belajar mengajar untuk pertemuan pertama siklus I dilaksanakan pada hari Senin tanggal 6 September 2021 di Kelas V dengan jumlah siswa 21. Adapun proses belajar mengajar mengacu pada rencana pelajaran yang telah dipersiapkan. Pengamatan (observasi) dilaksanakan bersamaan dengan pelaksanaan belajar mengajar. Pertemuan pertama ini diawali dengan kegiatan pendahuluan, kegiatan inti dan kegiatan akhir. Pada pertemuan kedua ini dilakukan sebagai upaya untuk memperbaiki proses pembelajaran yang belum maksimal pada pertemuan pertama. 
Optimalisasi Penggunaan Model Pembelajaran Word Square untuk Meningkatkan Hasil Belajar Siswa pada Tema Makanan Sehat di Kelas V SD Negeri 168/X Pandan Sejahtera, Nopri Samdi

Pertemuan kedua dalam siklus I ini dilaksanakan pada hari selasa tanggal 7 September 2021 dengan jumlah siswa hadir semuanya 21 orang. Pertemuan kedua ini kembali diawali dengan kegiatan pendahuluan, kegiatan inti dan kegiatan akhir.

\section{Observasi}

Sesuai dengan tujuan peneliti yaitu Optimalisasi Penggunaan Model Pembelajaran Word Square Untuk Meningkatkan Hasil Belajar Siswa Pada Tema Makanan Sehat Di Kelas V SD Negeri 168/X Pandan Sejahtera. Hasil belajar diperoleh dari lembar kerja siswa yang dilakukan pada setiap akhir siklus. Data yang diperoleh berupa angka mengenai hasil belajar yang diperoleh masing-masing siswa pada setiap siklus. Untuk lebih jelasnya hasil belajar siswa dapat dilihat pada tabel dibawah ini:

Tabel 2. Rekapitulasi Hasil Belajar Siswa Siklus I

\begin{tabular}{|l|c|}
\hline Jumlah & 1.335 \\
\hline Rata-rata & 63,67 \\
\hline KKM & 60 \\
\hline Siswa yang Tuntas & 12 Orang (57\%) \\
\hline Siswa yang Belum Tuntas & 9 Orang (43\%) \\
\hline
\end{tabular}

Dari tabel di atas dapat dijelaskan bahwa setelah menerapkan Model Pembelajaran Word Square pada siklus I ini di peroleh rata - rata hasil belajar siswa yaitu 63,67 dengan jumlah siswa yang tuntas sebesar 57\% (12 orang siswa) dan selebihnya $43 \%$ belum tuntas ( 9 orang siswa).

Dengan demikian, berdasarkan tabel hasil belajar siswa diatas serta penjelasannya dapat disimpulkan bahwa masih banyak siswa yang belum tuntas dalam belajar. Sehingga, masih terdapat 9 dari 21 siswa yang belum tuntas belajar atau sebesar 43\%. Hasil tersebut lebih kecil dari presentase ketuntasan klasikal dalam proses pembelajaran yang dikehendaki sebesar $80 \%$ siswa yang tuntas dalam belajar dengan KKM sebesar 60. Berdasarkan tabel lembar hasil belajar siswa dan penjelasan siklus I diatas dapat dilihat lebih jelas pada diagram dibawah ini:

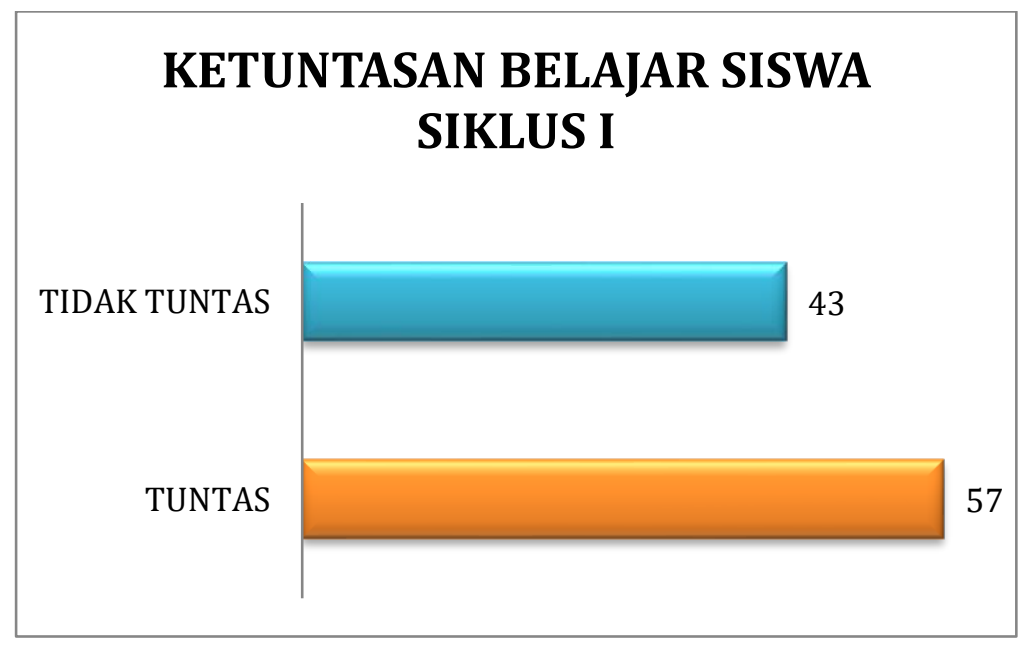

Diagram 2. Ketuntasan Hasil Belajar Siswa Siklus I 


\section{Refleksi}

Dalam tahap refleksi ini peneliti dibantu oleh observer (Agus Budi Hartono, S.Pd) menyampaikan temuan yang dilihat selama proses pembelajaran. Pertemuan ini dilakukan di ruang mejelis guru SD Negeri 168/X Pandan Sejahtera. Hasil diskusi yang dilakukan dengan observer bahwa adapun kekurangan yang ditemukan selam pembelajaran adalah guru kurang mempersiapkan diri dengan alat-alat/ media dalam rangka melengkapi bahan yang dibutuhkan seperti laptop, infokus, buku sumber dan lainnya yang berguna untuk menambah wawasan siswa dalam memahami materi membaca wacana tulis. Selain itu siswa kurang aktif dalam pembelajaran yang ditandai hanya sedikit yang mau bertanya dan menanggapi, selebihnya hanya diam saja dan tidak melakukan apapun, siswa masih banyak yang bingung dengan Model Pembelajaran Word Square.

Seharusnya guru harus mempersiapkan bahan, alat, sumber belajar saat berada didalam kelas sehingga siswa bisa memahami materi. Guru harus mampu membimbing siswa yang mempunyai kemampuan rendah dan kurang dalam menguasai materi, dan harus memberikan pengulangan pada materi yang diajarkan yang mungkin sulit atau kurang mengerti siswa, selalu memberikan motivasi atau semangat kepada siswa untuk selalu siap saat siswa melakukan pembelajaran. Menjelaskan terlebih dahulu kepada siswa mengenai model pembelajaran yang akan diterapkan. Dari masalahan diatas perlu dilakukan siklus selanjutnya, yaitu siklus ke II.

\section{Siklus II}

\section{Tahap Perencanaan}

Berdasarkan permasalahan yang diperoleh, ditetapkan langkah-langkah perencanaan tindakan sebagai berikut: Peneliti dengan observer mengadakan pertemuan untuk menentukan langkahlangkah yang harus dilaksanakan dalam penelitian ini. Peneliti merencanakan sekenario pembelajaran yang sesuai dengan kurikulum dan tingkat kemampuan awal siswa berdasarkan hasil kesepakatan bersama dengan observer untuk menyusun sekenario pembelajaran. Adapun sekenario pembelajaran sebagai berikut: Menyiapkan rencana pembelajaran sesuai dengan tujuan yang akan dicapai dalam pelajaran. Menyampaikan tujuan pembelajaran yang ingin dicapai. Perencanaan kegiatan inti pembelajaran dengan meggguanakan format penilaian yang sudah ditentukan. Merancang LKS yang akan digunakan saat siswa mengikuti kegiatan pembelajaran. Menyiapkan materi pembelajaran yang diperlukan saat berlangsungnya pembelajaran. Merencanakan model pembelajaran yang akan digunakan saat berlangsungnya penelitian. Menyiapkan format pengamatan proses pembelajaran saat berlangsungnya penelitian. Menyiapkan format penilaian hasil belajar. Menyiapkan hadiah.

\section{Tahap Pelaksanaan}

Pelaksanaan kegiatan belajar mengajar untuk pertemuan pertama siklus II dilaksanakan pada hari Rabu tanggal 8 September 2021 di Kelas V dengan jumlah siswa 21 orang. Adapun proses belajar mengajar mengacu pada rencana pelajaran dengan memperhatikan revisi pada siklus I, sehingga kesalahan atau kekurangan pada siklus I tidak terulang lagi pada siklus II. Pengamatan (observasi) 
Optimalisasi Penggunaan Model Pembelajaran Word Square untuk Meningkatkan Hasil Belajar Siswa pada Tema

dilaksanakan bersamaan dengan pelaksanaan belajar mengaja yang terdiri dari kegiatan pendahuluan, kegiatan inti dan kegiatan penutup.

Pertemuan kedua ini merupakan upaya untuk lebih memaksimalkan peningkatan proses pembelajaran agar hasil belajar siswa lebih meningkat dari KKM yang ditentukan. Pertemuan kedua dilaksanakan pada hari kamis tanggal 9 September 2021 dengan jumlah siswa 21 orang. Adapun pada pertemuan kedua diawali dengan kegiatan pendahuluan, kegiatan inti dan kegiatan akhir.

\section{Observasi}

Pada akhir proses belajar mengajar siswa diberi tes formatif II dengan tujuan untuk mengetahui tingkat keberhasilan siswa selama proses belajar mengajar yang telah dilakukan. Hasil belajar diperoleh dari lembar kerja siswa yang dilakukan pada setiap akhir siklus. Data yang diperoleh berupa angka mengenai hasil yang diperoleh masing-masing siswa. Untuk lebih jelasnya dapat dilihat hasil belajar siswa pada siklus II sebagai dapat dilihat pada tabel berikut:

Tabel 3. Rekapitulasi Hasil Belajar Siswa Siklus II

\begin{tabular}{|l|c|}
\hline Jumlah & 1.510 \\
\hline Rata-rata & $\mathbf{7 1 , 9 0}$ \\
\hline KKM & 60 \\
\hline Siswa yang Tuntas & 19 Orang $(91 \%)$ \\
\hline Siswa yang Belum Tuntas & 2 Orang $(9 \%)$ \\
\hline
\end{tabular}

Dari tabel di atas dapat dijelaskan bahwa pada siklus II ini dengan menerapkan Model Pembelajaran Word Square di peroleh rata - rata hasil belajar peserta didik yaitu 71,90 dengan jumlah siswa yang tuntas sebesar 91\% (19 orang siswa). Dengan demikian, berdasarkan tabel hasil belajar peserta didik diatas serta penjelasannya dapat disimpulkan bahwa dengan menggunakan Model Pembelajaran Word Square dapat meningkatkan hasil belajar siswa, karena sudah banyak siswa mencapai KKM (60). Sehingga model ini sangat cocok digunakan. Oleh sebab itu karena dalam penelitian ini sudah mencapai target maka siklus ini dihentikan.

Dengan demikian, berdasarkan tabel hasil belajar serta penjelasan diatas dapat disimpulkan bahwa sudah semua siswa yang berhasil dalam belajar. Hasil tersebut sudah baik dan memuaskan dibandingkan siklus II, sehingga target ketuntasan $80 \%$ sudah tercapai, oleh sebab itu maka siklus ini diberhentikan dan tidak perlu dilanjutkan kesiklus berikutnya. Berdasarkan tabel lembar aktifitas belajar siswa dan penjelasan pada siklus II diatas dapat dilihat lebih jelas pada diagram dibawah ini: 


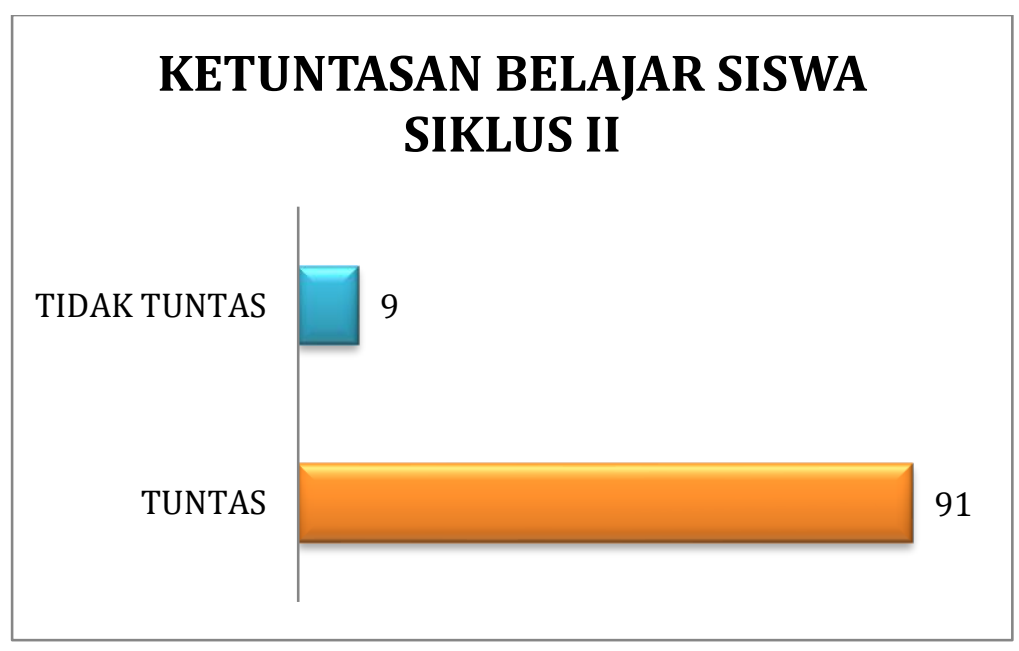

Gambar 3. Ketuntasan Hasil Belajar Siswa Siklus II

\section{Refleksi}

Berdasarkan hasil pengamatan peneliti dengan observer (Agus Budi Hartono, S.Pd) melakukan diskusi mengenai proses pembelajaran yang dilakukan diruang majelis guru. Adapun hasil diskusi yang dilakukan dengan observer dapat didiskripsikan bahwa pelaksanaan pembelajaran dengan menggunakan Model Pembelajaran Word Square pada siklus II dapat meningkatkan hasil belajar siswa. Sedangkan masalah-masalah yang ditemukan pada siklus I sudah teratasi baik itu dari guru maupun siswa itu sendiri, oleh sebab itu karena target dan ketuntasan sudah tercapai dan pendekatan yang diterapkan sudah berhasil dilaksanakan maka siklus ini dihentikan dan tidak perlu lagi dilanjutkan ke siklus berikutnya.

\section{Diskusi}

Berdasarkan hasil belajar siswa pada siklus I dan siklus II yang telah dilakukan oleh peneliti, maka terjadi perubahan yang dilihat selama penelitian pada hasil belajar siswa melalui hasil penilitian ini menunjukkan bahwa penggunaan Model Pembelajaran Word Square memiliki dampak positif dalam meningkatkan hasil belajar siswa. Hal ini dapat dilihat dari semakin mantapnya pemahaman siswa terhadap materi yang disampaikan guru (hasil belajar siswa meningkat mulai dari pra siklus, siklus I, dan II secara klasikal.

Pada pra siklus sebelum menerapkan Model Pembelajaran Word Square di peroleh rata - rata hasil belajar siswa yaitu 53,80 dengan jumlah siswa yang tuntas sebesar 14\% (3 orang siswa) dan selebihnya $86 \%$ belum tuntas (18 orang siswa). Dengan demikian, berdasarkan tabel hasil belajar siswa diatas serta penjelasannya dapat disimpulkan bahwa masih banyak siswa yang belum tuntas dalam belajar. Sehingga, masih terdapat 18 dari 21 siswa yang belum tuntas belajar atau sebesar $86 \%$. Hasil tersebut lebih kecil dari persentase ketuntasan klasikal dalam proses pembelajaran yang dikehendaki sebesar 80\% siswa yang tuntas dalam belajar dengan KKM sebesar 60 .

Setelah menerapkan Model Pembelajaran Word Square pada siklus I ini di peroleh rata - rata hasil belajar siswa yaitu 63,67 dengan jumlah siswa yang tuntas sebesar 57\% (12 orang siswa) dan 
Optimalisasi Penggunaan Model Pembelajaran Word Square untuk Meningkatkan Hasil Belajar Siswa pada Tema Makanan Sehat di Kelas V SD Negeri 168/X Pandan Sejahtera, Nopri Samdi

selebihnya $43 \%$ belum tuntas ( 9 orang siswa). Dengan demikian, berdasarkan tabel hasil belajar siswa diatas serta penjelasannya dapat disimpulkan bahwa masih banyak siswa yang belum tuntas dalam belajar. Sehingga, masih terdapat 9 dari 21 siswa yang belum tuntas belajar atau sebesar 43\%. Hasil tersebut lebih kecil dari presentase ketuntasan klasikal dalam proses pembelajaran yang dikehendaki sebesar $80 \%$ siswa yang tuntas dalam belajar dengan KKM sebesar 60.

Pada siklus II ini dengan menerapkan Model Pembelajaran Word Square di peroleh rata - rata hasil belajar peserta didik yaitu 71,90 dengan jumlah siswa yang tuntas sebesar 91\% (19 orang siswa). Dengan demikian, berdasarkan tabel hasil belajar peserta didik diatas serta penjelasannya dapat disimpulkan bahwa dengan menggunakan Model Pembelajaran Word Square dapat meningkatkan hasil belajar siswa, karena sudah banyak siswa mencapai KKM (60). Sehingga model ini sangat cocok digunakan. Oleh sebab itu karena dalam penelitian ini sudah mencapai target maka siklus ini dihentikan.

Berdasarkan analisis data, diperoleh hasil belajar siswa dalam proses pembelajaran dengan menggunakan Model Pembelajaran Word Square dalam setiap siklus mengalami peningkatan. Hal ini berdampak positif terhadap hasil belajar siswa yaitu dapat ditunjukkan dengan meningkatnya nilai rata-rata siswa pada setiap siklus yang terus mengalami peningkatan. Untuk lebih jelasnya dapat dilihat grafik dibawah ini:

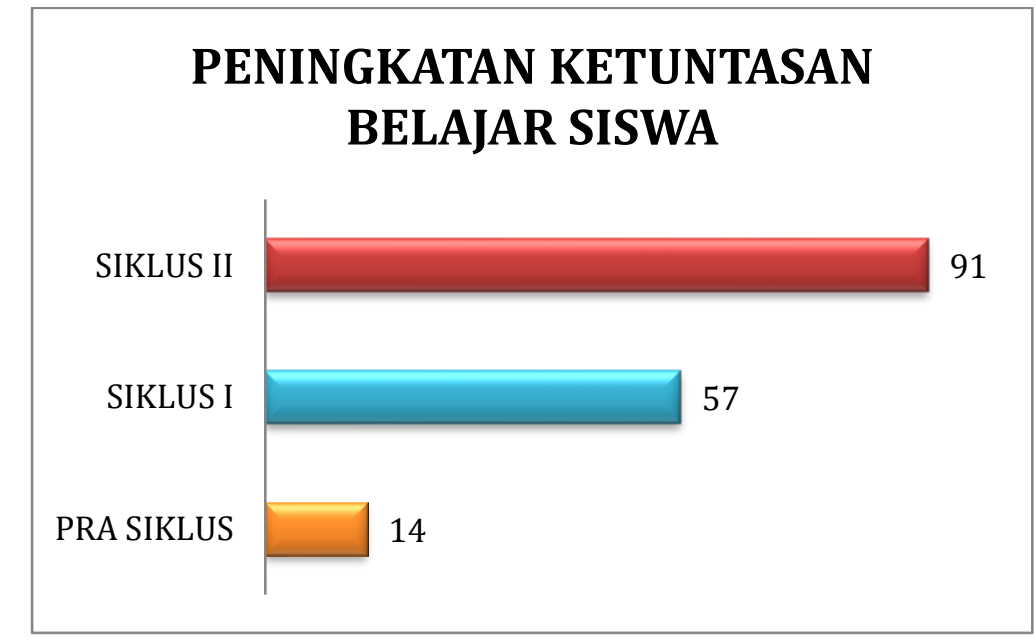

Gambar 4. Peningkatan Ketuntasan Hasil Belajar Siswa

\section{KESIMPULAN}

Berdasarkan analisis, temuan dan pembahasan yang diuraikan pada bab sebelumnya tentang Optimalisasi Penggunaan Model Pembelajaran Word Square Untuk Meningkatkan Hasil Belajar Siswa Pada Tema Makanan Sehat Di Kelas V SD Negeri 168/X Pandan Sejahtera dapat disimpulkan bahwa Proses pembelajaran dengan menggunakan Model Pembelajaran Word Square dapat meningkatkan hasil belajar siswa. Peningkatan hasil belajar siswa dapat dilihat dari pra siklus, siklus 1 dan siklus II. 
Dari hasil penelitian yang diperoleh dari uraian sebelumnya agar proses belajar pembelajaran lebih efektif dan lebih memberikan hasil yang optimal bagi peserta didik, maka saran sebagai berikut:

1. Untuk melaksanakan Model Pembelajaran Word Square memerlukan persiapan yang cukup matang, sehingga guru harus mampu menentukan atau memilih topik yang benar-benar bisa diterapkan dengan Model Pembelajaran Word Square dalam proses belajar mengajar sehingga diperoleh hasil yang maksimal.

2. Dalam rangka meningkatkan hasil belajar siswa, guru hendaknya lebih sering melatih siswa dengan berbagai metode pengajaran, walau dalam taraf yang sederhana, dimana siswa nantinya dapat menemukan pengetahuan baru, memperoleh konsep dan keterampilan, sehingga siswa berhasil atau mampu memecahkan masalah-masalah yang dihadapinya.

3. Perlu adanya penelitian yang lebih lanjut, karena hasil penelitian ini hanya dilakukan di kelas $\mathrm{V}$ SD Negeri 168/X Pandan Sejahtera semester I tahun pelajaran 2021 - 2022.

4. Untuk penelitian yang serupa hendaknya dilakukan perbaikan-perbaikan agar diperoleh hasil yang lebih baik.

\section{REFERENSI}

Agus Suprijono. 2009. Cooperative Learning, Teori \& Aplikasi PAIKEM. Surabaya: Pustaka Pelajar। Agus, Suprijono. 2012. Cooperative Learning: Teori dan Aplikasi Paikem. Yogyakarta: Pustaka Pelajar.

Anonim. 1991. Kimia Tanah. Direktorat Jendral Pendidikan. Departemen Pendidikan dan Kebudayaan. Jakarta.

Arikunto, Suharsimi. 1992. Prosedur Penelitian Suatu Pendekatan Praktik. Jakarta: PT Rineka Cipta.

Endang Komara. (2014). Belajar dan Pembelajaran Interaktif. Bandung: PT Refika Aditama.

Gagne. Robert M, 1984. Kondisi Belajar dan Teori Pembelajaran. (terjemah Munandir). PAU Dirjen Dikti Depdikbud. Jakarta.

Hanafiah, dan Cucu Suhana. 2009. Konsep Strategi Pembelajaran. Bandung: PT Refika aditama.

Hornby, A. S, 1994, Oxford Advanced Learner's Dictionary, New York: Oxford University Press.

Iskandar. 2009. Metodologi Penelitian Kualitatif. Jakarta: Gaung Persada Press.

Istarani. (2012). 58 Model Pembelajaran Inovatif. Medan: Media Persada.

Laurence Urdang.1968. Word Square.New York: Random House.

Mujiman, Haris. 2007. Manajemen Pelatihan Berbasis Belajar Mandiri. Yogyakarta: Mitra Cendekia.

Nana Sudjana. (2002). Penilaian Hasil Proses Belajar Mengajar. Bandung: Remaja Rosdakarya.

Pribadi, Benny A. 2011. Model Desain Assure untuk Mendesain Pembelajaran Sukses. Jakarta: Dian Rakyat.

Rusman, 2009. "Manajemen Kurikulum “. Jakarta : PT Raya Grafindo Persada.

Slameto. 2010. Belajar dan faktor-faktor yang Mempengaruhinya. Jakarta: PT. Rineka Cipta. 
Optimalisasi Penggunaan Model Pembelajaran Word Square untuk Meningkatkan Hasil Belajar Siswa pada Tema Makanan Sehat di Kelas V SD Negeri 168/X Pandan Sejahtera, Nopri Samdi

Trianto, 2011, Model Pembelajaran Terpadu Konsep,Strategi Dan Implementasinya Dalam Kurikulum Tingkat Satuan Pendidikan (KTSP), Jakarta : Bumi Aksara

Trianto. 2010. Model Pembelajaran Terpadu, Konsep, Strategi dan Implementasinya dalam KTSP. Jakarta: Bumi Aksara

Trianto. 2012. Model Pembelajaran Terpadu. (Jakarta: PT Bumi Aksara).

Undang-Undang Dasar 1945 pasal 31 ayat 1

Undang-Undang Guru dan Dosen pasal 1 ayat (1)

Undang-Undang nomor 20 tahun 2003

Uno B. Hamzah, 2011. Teori Motivasi dan Pengukurannya Analisis di Bidang Pendidikan, Jakarta: PT. Bumi Aksara

Yamin, M. 2002. Pengaruh tingkat protein ransum terhadap konsumsi pertambahan bobot badan dan IOFC ayam buras umur 0-8 minggu. Jurnal Agroland Vol.9 No. 3 September 2002. 